\title{
Nella Last's War Diary: \\ The Silent Witness of Self-Therapy and the Emergence of Self-Identity and Independence through Writing and Volunteerism
}

\author{
By Patricia Brand
}

"We who remember the long-drawn-out agony of the last war feel ourselves crumble somewhere inside at the thought of what lies ahead."1 Nella Last, British housewife and mother, penned these words in her Mass-Observation diary on Thursday, 14 September 1939, the day before her youngest son Cliff left for active duty in the Second World War. Those who had served and suffered on the battlefields of World War One, and those who had served on the home-front, survived to share in the disastrous effects of modern warfare in post-war Britain. Amputations, maimed bodies and faces from the burn of poisonous gases, the trauma of "shell shock" as well as personal and national financial impoverishment had failed to teach world leaders that war begets war. Disillusionment, and a feeling of profound personal loss plagued the generation who had fought World War One. They had discovered the war that had been promised "to end all wars" had in truth been a breeding ground for the rise of totalitarian regimes that would ignite another world war, once again to claim the lives of sons and daughters, husbands and wives, friends, and lovers.

The Mass-Observation project that Nella and over four-hundred British citizens participated in was first initiated in 1937 by anthropologist Tom Harrisson. The objective of the movement stated by its founder was to create a study of Britain, to observe and record the opinions, attitudes, and activities of the people. Initially, Tom Harrisson conducted an ethnographic study in the town of Bolton, England. Harrisson acted as a participant-observer among the citizens of the town; observing and recording their behavior as well as collecting information from the study group through interviews. After the war began participants responded to survey questions posed by Harrisson and analyzed by trained specialists. In the final phase of the study people were asked to volunteer to make personal

\footnotetext{
${ }^{1}$ Richard Broad and Suzie Fleming, ed., Nella Last's War: The Second World War Diaries of Housewife (London: Profile Books, Ltd.), 7.
} 


\section{Patricia Brand}

observations in a diary about their daily lives. Once a month, mass observers were asked to write about their personal opinions and beliefs on a variety of topics such as religion, marriage, and death. The data collected from diarists and opinion surveys provided a micro and macro level perspective of British society

A growing number of historians and practicing psychoanalysts have examined diaries of different groups such as wartime writers, victims of abuse, and veterans of war as well as students who are engaging in the process of self-writing. Findings indicate that keeping a diary acts as a type of self-therapy that has proven beneficial in the processing of painful, life-altering memories that tend to inhibit self-growth. Wendy Wiener and George Rosenwald note in A Moment's Monument: The Psychology of Keeping a Diary, "Rather than ask what life experiences have survived repression, we might accordingly do better to study what the subject has selected for preservation. For the act of remembrance is a choosing, a highlighting, a shaping, an enshrinement (even when it hurts). A life story is not simply that which has escaped forgetting." 2 It is of interest to note here that diary-keeping and journaling was a common practice prior to and during World War Two and is a rich source of knowledge about the experiences of those who lived during this traumatic time.

Historian James Hinton examined the diaries of Nella Last and eight other Mass Observation diarists in his book entitled Nine Wartime Lives and argued:

They were people on a quest, looking for meaning and purpose in their lives beyond the mundane satisfactions of everyday life, feeling a need to participate in society not only as members of families and friendship networks, consumers, and workers, but also as active citizens making a voluntary contribution to the greater social good. ${ }^{3}$

Hinton also argued that a sense of "dutiful active citizenship" inspired Nella Last and the other women he wrote about in the biographical narratives from Mass

\footnotetext{
${ }^{2}$ Wendy Wiener and George Rosenwald, A Moment's Monument: The Psychology of Keeping a Diary in R. Josselson and A. Lieblich, eds., The Narrative Study of Lives (London: Unknown Publisher, 1993), 31.

${ }^{3}$ Hinton, Nine Wartime Lives, 204.
} 
Observation. He noted, "Their stories can be read as testimony either to the long after-life of Victorian notions of 'character,' or as skirmishes in a struggle for female equality in the intimate sphere." ${ }^{4}$ After researching Nella's life story and reading her diary entries, Hinton concluded that regardless of Nella's achievements and progress in self-development, her inability to gain autonomy was caused by her "weak streak," and this was the reason she remained with her husband, Will. ${ }^{5}$ In regard to this Hinton wrote:

Nella Last, for all the vigour of her self-assertions, remained trapped in her unsuitable marriage, fearful that whatever gains she had made would not outlast the war. It would be, she believed, for the next generation to establish autonomy which her 'weak streak' had prevented her from laying down earlier in her own marriage. ${ }^{6}$

I argue that rather than answering to the call of "dutiful active citizenship," Nella used the diary she submitted to Mass- Observation as a survival strategy in a twofold way: to help her live through the war and control the great fear that her youngest son, Cliff, would be killed in combat as well as to aid her in avoiding a second nervous breakdown. ${ }^{7}$ In addition, I argue that Nella's diary became a multifunctional tool she employed as a confidant as well as a record of the development of independence and self-identity she gained through volunteerism in the war effort and participation in the Mass-Observation project. It was through these two avenues that Nella Last, wife and mother, did achieve independence and autonomy: the ability to depend on one's self and govern one's self.

The repression and isolation of Nella by her husband, Will Last, resulted in continual health problems and a complete nervous breakdown in the years prior to the war. Through the examination of Nella's diary, her thoughts and feelings can be observed as she records sad and happy times, cruel repression from her husband and times of self-victory, the relentless fear of losing her sons through

\footnotetext{
${ }^{4}$ Hinton, Nine Wartime Lives, 204.

${ }^{5}$ Ibid., 202.

${ }^{6}$ Ibid.

${ }^{7}$ Ibid., 204.
} 


\section{Patricia Brand}

the violence of war to becoming a stalwart figure for other mothers to lean on through her courageous spirit.

Nella's growing relationship with her diary provided a healing self-therapy that resulted in the personal discovery that she was strong and self-reliant in times of personal and national crisis. The middle-age housewife who felt so belittled and unaccomplished before the war due to demeaning criticism and control by her husband, accomplished what might be considered a lifetime of growth in a short period of time. Evidence of Nella's resolve to overcome the limitations placed on her can be witnessed by the considerable political space she cleared for the development of selfhood while remaining in the place her Victorian training had taught her that she belonged; staying by her husband's side and taking care of him, and as she had promised Cliff, she would "keep the home fires burning." 8

On 3 September 1939 France and Great Britain declared war on Germany. It was also the first day that Nella Last began writing in her diary. On that frightful day that all of Britain had feared, Nella shared her first confidence in her diary when she said, "I'm a self-reliant kind of person, but today I've longed for a close woman friend-for the first time in my life."9 Nella felt the intensity of a building vacuum in her life because her son Cliff, whom she regarded as her closest friend, would leave for the war within a few days, and her eldest son and strong supporter, Arthur, was already training as a tax examiner for the war effort in London. The diarist wrote of her pain when she thought of Cliff being subjected to violence as well as doing violence to others. She said in her Thursday, 14 September 1939 entry, "It's dreadful to think of him having to kill boys like himself - to hurt and be hurt. It breaks my heart to think of all the senseless, formless cruelty." 10 Regardless of Nella's emotional needs she could not turn to her husband for comfort or solace as her anxiety built in anticipation of Cliff's departure, because she had been waging a personal war for survival since the beginning of her marriage to a man who treated her feelings with disregard, demanded her

\footnotetext{
${ }^{8}$ Broad and Fleming, Nella Last's War, 93.

${ }^{9}$ Ibid., 2.

${ }^{10}$ Ibid., 7.
} 
acquiescence in all matters, and manipulated the isolation of Nella that sapped her strength and joy for life.

At the heart of the marital problems that sorely afflicted Nella's life were the vast differences between her personality and that of her husband. When they first met, Nella was a light-hearted, happy individual who thrived in the company of friends, family, and active social circles. Will Last, on the other hand, was serious, remote in his personality, and craved the solitude and privacy of their home and isolation from social situations; more importantly, he wanted this for Nella and his sons as well. Making matters worse, class conflict created a wedge between the couple that chipped away at the family's solidarity. Nella was born into the middle-class and Will's family was part of the working-class of Barrow-inFurness, the town where he grew up, and where they lived together. Strife between the couple escalated due to the interference of Will's family and their disapproval of his wife who had aspirations of elevating their growing family to the level of middle-class. Will was dismissive of his wife's middle-class desires as well as how she encouraged the boys to invite their friends to the house where she too would enjoy their company. When the boys were of school age Nella carefully planned for the future of her son's education as well as lessons in the social arts; this also made Will unhappy as he thought it unnecessary. Speaking of this Nella wrote in her Monday, 21 October 1940 diary entry:

I wonder if all parents - mothers anyway - feel the same towards their boys, and want them to have chances they did not have in life. Me - I've always missed things, somehow. Ill health and other circumstances have always beaten me, however much I tried to do things - and also my 'weak streak', as the boys call it, that could never be ruthless and made me give up many a cherished plan when it would give pain or annoyance to others. Weak I might be on top, but not underneath. Down underneath, I fought - and plotted - all for my boys. No woman ever had two such boys, I feel! Such nice men they are - and they like me which is my crown and joy. ${ }^{11}$

\footnotetext{
${ }^{11}$ Broad and Fleming, Nella Last's War, 72.
} 
Will did not share in Nella's feelings of pride for their two sons. He said, "neither of the boys are like other people's lads," to which she retorted: "well so what, hasn't that always been the battle cry of your folks about me?"12 Perhaps the most troubling aspect of Will's dominance of Nella were the actions he took to keep her at home, tending to his needs and demands, while keeping her friends and family at bay through his sullen and unfriendly manner. Nella's inability to cope effectively with the stress and pressure placed upon her by Will and his family, altered her outlook on life, making her uncertain of her position and greatly afflicting her health.

Nella's health problems had haunted her throughout her marriage with a long list of reoccurring symptoms that seemed to be random, but intense when they appeared: heart trouble, anxiety, vomiting, the inability to eat, and extreme frustration. In 1937 and 1938, Nella suffered a complete nervous breakdown that affected her ability to walk. Initially, the diagnosis of her ailment was multiple sclerosis, but new medical knowledge had recently surfaced that suggested symptoms such as Nella's were not always physical, but sometimes psychological. Nella's ongoing physical problems had puzzled Dr. Millar, her general practitioner, due to the fact that she was strong and had basic good health as well as a healthy lifestyle. For some time, the doctor suspected that his patient's problems were emotional rather than physical, because of different experiences she shared in the privacy of the doctor/patient relationship. Dr. Millar decided his only alternative in saving the health of his patient was to visit her home and confront Will about Nella's condition. Dr. Millar openly challenged Will, saying, "Do you know the meaning of repression? ... What would happen to a kettle if you put a cork in the spout and tied the lid down tight and yet kept it at boiling point?"13

From this juncture, the doctor had finally broken through the barrier he had heretofore been unable to penetrate because of Nella's inability to understand the cycle of health problems she was experiencing was due to the continual emotional and mental assault by her husband that resulted in physical problems. The doctor

\footnotetext{
${ }^{12}$ Hinton, Nine Wartime Lives, 26.

${ }^{13}$ Ibid., 26.
} 
counseled his patient to go out and enjoy the company of friends. He also encouraged Nella to overcome the Victorian notion that her husband could not prepare food for himself if she was not at home. Nella and the doctor had finally made a breakthrough in the long years of physical and emotional suffering. Dr. Millar warned his patient that if she continued to stay at home in the repression and isolation that had wrapped around her life like a cocoon she would indeed suffer another nervous breakdown. Life for the forty-nine-year-old housewife and mother changed as she began to work through the emotional and physical trauma with voluntary war-work and the self-therapy she was receiving through her MassObservation diary.

The entries in Nella's diary bear witness to the fact that she followed the advice of her doctor and made great strides in an effort to get out of the house and among other people as well as work to transform her life with voluntary work at the Women's Voluntary Service (WVS), and Hospital Supply, also called 'the Centre.' In this position Nella and other women who volunteered worked together to mend old donated clothing and turn them into blankets for sailors. Raffles were held daily to garner money to buy wool for volunteers at the 'Centre' to knit into articles of clothing for sailors. The transition from being essentially housebound and isolated to being in a highly public and active place was a large emotional and physical step; however, Nella's efforts to take positive actions resulted in the beginning of transformations that would change the course of her life.

Voluntary wartime work acted as a catharsis for Nella who was struggling not only with her own fears, but with the growing fear of German invasion that the British people were feverishly preparing for. In the Monday, 11 September 1939 entry Nella bravely announces her plans and charts her progress as she writes in her diary:

Other friends look aged, and I have a cold feeling down inside when I think of my Cliff off on Friday. I will dedicate every part of my time when I'm not looking after my husband to the W.V.S. I'll work and beg things and keep cheerful outwardly at least. Now when I plan and work harder, I find my brain sharper and I don't forget things. I'm following my doctor's advice and have 
not lost any more weight. I can sleep at least four hours a night and, although always tired, have not been so exhausted. ${ }^{14}$

Again, in the Tuesday, 19 September 1939 entry the diarist writes of more progress with establishing contacts and activity away from home. Although proud of her gains, she confides in her diary fear and uncertainty for the future:

\begin{abstract}
Arthur (my older boy) thinks it's a 'wonderful philosophy' of mine to try and 'take each day as it comes and do the best I can with it', but it's not, it's just a kind of fear to look ahead. I'm just a woman who sees all the simple joys turning into luxuries that no amount of money could buy. ${ }^{15}$
\end{abstract}

This was indeed a difficult time in Nella's life, for she knew that to return to living in a controlled and isolated environment would be disastrous for her health, but for the first time in many years she faced the future alone with Will, because the presence and support of Cliff and Arthur had been interrupted by the war. Courage and determination pushed Nella forward in pursuit of establishing personal freedom as well as coping with the burdens of war that occupied her days. In the entry of Thursday, 29 February 1940 Nella confided in her diary:

Some days I am so busy I can only think of what I'm doing, or the immediate tasks ahead, and I'll have a static feeling of happiness-a rhythm of mind-when the realisation of WAR sweeps over me: for one dreadful second I could scream like a horse and a wave of coldness breaks over me. It passes, but I wonder what I would do if my days were not so full-and thank God I can work-not only for the bit I do, but for the strength it gives me to go on. ${ }^{16}$

Nella's writing clearly indicates that the war work she committed to was having beneficial effects for her physical well-being by occupying her days and keeping her thoughts distracted from the realities of war.

Wiener and Rosenwald theorized that recording one's chosen memories in a diary could aid in a self-progressive state. They noted:

\footnotetext{
${ }^{14}$ Broad and Fleming, Nella Last's War, 6.

${ }^{15}$ Ibid.

${ }^{16}$ Ibid., 32-33.
} 
Biographical memory saves our most promising projects of selftransformation, and new living action seeks to complete and extend these. The diary preserves both poles of the transformation. Like a screen memory, it contains a partial representation of that which was in need of mastery as well as the record of its overcoming. The reminders of the old frailty have been covered over with a chronicle of acquired fitness. ${ }^{17}$

Nella's diary entries are witness to the fact that in many ways the diarist used the technique described by Wiener and Rosenwald to record her troubled past with Will, but she also wrote about positive actions she was taking with her voluntary work as well as her efforts to relinquish the Victorian enculturation she had received as a female child to obey unquestionably the teachings of an outdated patriarchal system. This endeavor empowered Nella at a time that was critical to her well-being as the stress of the war weighed heavily on the strained relationship between Nella and Will.

In response to a monthly directive by Mass-Observation on the topic of sex, Nella expounded on the traditional roles that women were expected to perform in Victorian Britain. In the Sunday, 15 June 1941 entry she wrote, "A woman was expected-and brought up- to obey, and we had not got far from the days of Victorian repression: men expected to be masters in matters widely to do with sex. No woman was ever expected to be out, for instance, when her husband came in for a meal." ${ }^{18}$ Nella's voluntary war-work had provided her with the opportunity to be a member of a group of women who had moved beyond many of the limitations women had suffered under the patriarchal system, and this encouraged Nella to act boldly in her own self-interest. The diarist commented on her progress with this matter in the Thursday, 14 March 1940, entry:

I reflected tonight on the changes the war had brought. I always used to worry and flutter round when I saw my husband working up for a mood; but now I just say calmly,' Really dear, you should try and act as if you were a grown man and not a child of

\footnotetext{
${ }^{17}$ Wiener and Rosenwald, $A$ Moment's Monument, 17.

${ }^{18}$ Broad and Fleming, Nella Last's War, 151.
} 


\section{Patricia Brand}

ten, and if you want to be awkward, I shall go out - ALONE ! ${ }^{19}$

As a result of her work at 'the Centre,' Nella was asked if she would be willing to work at the WVS canteen, managing and advising in the preparation of meals for military personnel as well as collecting supplies for the canteen. It was in this capacity that Nella blossomed and became highly regarded by the WVS for applying her homemaking skills of frugality and culinary arts to help in the creation of nutritious and attractive meals with only sparse supplies. Skills that heretofore in her home environment had drawn laughter from her husband, gained a certain level of fame and praise at the canteen. In the Thursday, 28 August 1941 entry Nella writes of the new opportunity offered to her by Mrs. Thompson, head of the canteen, and with confidence and excitement she wrote:

She wants me to give an afternoon and/or evening as advisory cook. She says I'll not have to work really hard, only overlook and give advice on economical and tasty oddments. Mrs. Diss, who has taken over as head of W.V.S. had sent her. It's what I've always wanted to do-I am realising more each day what a knack of dodging and cooking and managing I possess, and my careful economies are things to pass on, not hide as I used to do! ${ }^{20}$

Nella's transformation from being homebound, to being a team member of a large workforce, to taking on managerial roles at the WVS canteen was testimony to the diarists' commitment to her self-development that she followed and documented in her diary with dedication. The woman who had suffered a complete nervous breakdown from severe repression was beginning to thrive on the opportunities that wartime offered women. Traditional restrictions that usually barred women from positions of leadership and male-dominated work was of necessity removed as women were forced out of the home and into the public sphere to aid in the war effort. The liberating conditions of wartime Britain presented the perfect opportunity for Nella to throw-off the domination of Will, and she came to realize her skills were indeed of value to other people. By

\footnotetext{
${ }^{19}$ Broad and Fleming, Nella Last's War, 37.

${ }^{20}$ Ibid., 160.
} 
accepting new challenges, she was laying the groundwork for the creation of political space that she was quickly building in her public life as well as her home life.

Nella's determination to move beyond Will's inclinations to make life decisions for her regardless of her personal preferences can be seen in the Friday, 22 November 1940 entry. Will had been admiring Nella's new permanent wave and he voiced his desire for her to always look the way she did, to never have to work, and to be dressed in fine garments that he knew she liked. Nella responded with a strong rebuttal saying:

I suppose you would only think I was putting a brave face on if I told you I'd sooner die than step into the frame you make for me. Do you know, my dear, that I've never known the content - at times, real happiness - that I've known since the war started? Because you always thought like that and were so afraid of 'doing things', you have at times been very cruel. Now my restless spirit is free, and I feel strength and endurance comes stronger with every effort. ${ }^{21}$

Anthony Giddens wrote in his book, Modernity and Self-Identity: Self and Society in the Late Modern Age a method whereby an individual could bring about change in their life by employing the suggestions of Janette Rainwater, clinical psychologist. Giddens wrote that she emphasized, "Living every moment reflectively is a matter of heightened awareness of thoughts, feelings and bodily sensations. Awareness creates potential change, and may actually induce change in and through itself." 22

The beneficial effects of Nella's writing developed into a quiet time of contemplation, a pondering of past and present events in her life, and thereby became a self-therapy, as suggested by Giddens and Rainwater. A reflective moment by Nella can be witnessed in her diary entry of Thursday, 28 August 1941. Mrs. Diss, head of the WVS, had invited Nella to take an advisory position at the canteen. Will commented about Nella's willingness to accept more work

\footnotetext{
${ }^{21}$ Broad and Fleming, Nella Last's War, 82-83.

${ }^{22}$ Anthony Giddens, Modernity and Self-Identity: Self and Society in the Late Modern Age (Cambridge: Unknown Publisher, 1991), 71.
} 


\section{Patricia Brand}

and responsibility. He said, "You know, you amaze me really, when I think of the wretched health you had just before the war, and how long it took you to recover from that nervous breakdown." 23 Nella was honest, but kind in her return comments:

Well, I'm in rhythm now, instead of always fighting against things' - but stopped when I saw the hurt, surprised look on his face. He never realizes - and never could - that the years when I had to sit quiet and always do everything he liked, and never the things he did not, were slavery years of mind and body." 24

As a result of Nella's exemplary work at 'the Centre' and WVS canteen, in July of 1942, Tom Cross, Red Cross organizer, and Mrs. Diss approached her to see if she and a few others who worked at the canteen would care to locate a building for a Red Cross shop and gather donations of clothes, toys, and other household items to be sold to aid in the funding of parcels for British prisoners of war. Nella found a shop rent-free and formed a committee of women she believed would work well together. It was in this shop that Nella truly came into her own organizing and acquiring donations. In her diary entry of Thursday, 23 July 1942 Nella enthusiastically wrote, "Our shop is for the Prisoner of War Fund, so we may tap a fresh source of money. I've talked to everyone I know, and got lots of bits and bobs promised." 25 Nella's leadership skills were made apparent as she smoothly coordinated the work and led the management of the shop. In her spare time, she created her dollies, rag-babies, and rag-bunnies to be donated for auction for the funding of prisoner of war parcels as well as for supplies at 'the Centre.'

The Red Cross shop began to flourish under the creative imagination and energy that Nella generously directed to the project. Dedicated volunteers worked tirelessly by her side and followed her lead by helping to create a thriving business to gather money for the prisoners of war. Nella wrote in her diary Tuesday, 1 September 1942:

\footnotetext{
${ }^{23}$ Broad and Fleming, Nella Last's War, 160.

${ }^{24}$ Ibid.

${ }^{25}$ Ibid., 204.
} 
People are getting to know about us and will give us things, though they must be reminded constantly, and we must all make any toys or fancy articles for Christmas. But keep it open we must and shall. I've told all the helpers they have not to 'try', they have to $d o$ it, and all must beg and beg. A hundred pounds is a marvelous thing - two hundred parcels of hope and comfort to heartsick men. Who knows who will be the next man to need a parcel? Any of our menfolk who have gone overseas. ${ }^{26}$

When the war came to a close, Nella and her fellow- workers would remember their experiences in the Red Cross shop as some of their finest moments in their voluntary war-work. Monday, 18 June 1945 Nella confided in her diary feelings of sadness as the Red Cross shop was due to close at the end of the war. She wrote:

No one could have realised what that little junk-shop has been to me. I loved it, and felt a blessing from every $10 \mathrm{~s}$ we raised. It's not been always easy going. I've had a few fights, even if they were quiet ones. It grew and grew. We never knew the happiness we brought to the poor P.O.W.s, but could feel our work was worthwhile. I felt I was a soldier like my Cliff - and we will be demobbed about the same time. ${ }^{27}$

Wartime volunteerism and participation in the Mass-Observation project would be Nella's greatest self-victory and some of the happiest and most fulfilling times of her life aside from her fond memories of the boy's childhood days. It is of interest to note that the diarist was open and revealing about the sad and difficult times of her life as she wrote of intimate details of her great fear that Cliff might be killed in active combat in Italy and the Middle East, the loss mothers endure during wartime as well as her concerns for the future relationship between her and Will that loomed ahead in the post-war years.

Suzette A. Henke, Sr. professor of Literary Studies at the University of Louisville, initiated a study of women's life-writing in 1985. She found in the women's literature she was examining a significant number of women writing in journals and diaries about physical and emotional symptoms they experienced associated with past traumas. Symptoms recorded in the women's literature were

\footnotetext{
${ }^{26}$ Broad and Fleming, Nella Last's War, 208.

${ }^{27}$ Ibid., 281.
} 


\section{Patricia Brand}

consistent with those experienced by World War One veterans diagnosed with "shell shock, "or the fear of "active combat." 28 Those who were diagnosed with "shell shock," known today as Post-Traumatic Stress Disorder, suffered from: unwanted, repetitious and disturbing memories of the past, physical ailments produced by the memories such as nausea, pounding heart, muscle tension, guilt, shame, and feelings of being alienated. It is pertinent at this point to acknowledge that many of the symptoms associated with Post-Traumatic Stress Disorder were also the symptoms Nella suffered frequently and wrote about in her diary on a regular basis such as heart trouble, muscle tension, guilt, nausea, shame, and especially disturbing memories of past events as well as the feeling of being alienated.

Henke's findings led her to theorize that writing about trauma one was currently experiencing could be as effective as writing about past trauma and may well be as helpful as psychoanalysis. Henke wrote about the benefits of autobiographical writing in her book, Shattered Subjects: Trauma and Testimony in Women's Life Writing, the author claimed, "Autobiography could so effectively mimic the scene of psychoanalysis that life-writing might provide a therapeutic alternative for victims of severe anxiety and, more seriously, of post-traumatic stress disorder." ${ }^{29}$ Henke supported her theory with the written work of practicing therapist, Judith Lewis Herman titled, Trauma and Recovery. Herman's book presented a significant number of actual clinical cases in her practice who worked through trauma with life-writing. Henke stated, "As a practicing therapist, Herman was able to compare post-traumatic stress disorder precipitated by rape, sexual abuse, or battering with the symptoms of neurosis exhibited by war veterans and victims of terrorism." ${ }^{30}$ Combining her own research and findings as well as the case histories and life-testimonials submitted in Herman's book, Henke theorized that different forms of autobiographical writing aided in analyzing one's own history, thereby helping to establish empowerment through self-examination.

${ }^{28}$ Suzette A. Henke, Shattered Subjects: Trauma and Testimony in Women's Life Writing (New York: Saint Martin's Press, 1998), xi.

${ }^{29}$ Henke, Shattered Subjects, xii-xiii.

${ }^{30}$ Ibid., xiii. 
Henke noted a common element of women's writing as, "Women daring to name themselves, to articulate their personal histories in diary, memoir, and fictional form, reinscribe the claims of feminine desire onto the texts of a traditionally patriarchal culture." 31

Scholars Hinton and Henke offer a much different evaluation of autobiographical writing that emerges for the diarist. Hinton perceived the diary when writing about Mass Observation diarists' as a venue to fulfill their duty to the country, rather than acknowledge the self-discovery that occurred as the diarist records events, both good and bad, to be viewed in a physical format for analysis. On the other hand, Henke perceived the scene of autobiographical writing as a forum to record major events in one's life as well as repetitious inner dialogue, and grant authority to one's self to reflect on past events. Henke noted that often self-reflection could be a point of liberation and as effective as professional psychological help. Nella's honest, and at times blunt truthfulness about her life experiences demonstrates that she was reflecting back on past events and working to find ways to resolve personal conflict.

Nella's determination to maintain her physical, emotional, and mental health throughout the terrible war years can be witnessed through the life-writing the diarist practiced. As suggested by Suzette Henke, writing about the trauma, during the trauma, seemed to give Nella the inner-strength to carry on when dark times engulfed her. Nella penned Sunday, 6 April 1941 in her diary entry about the traumatizing thoughts and fears she had for the safety of her sons, she wrote," I pictured terror and fear in the big cities, and thought of how I'd lost my life-long love of the sea and rolling, tossing waves - it made me think of shipwrecked men in little boats, of men left to drown when their ships were attacked by submarines." 32

Tuesday, 9 March 1943 Nella comforted one of the mothers who worked at 'the Centre,' because her son had just been killed in Rzhev, Russia. The grieving

\footnotetext{
${ }^{31}$ Henke, Shattered Subjects, xvi.

${ }^{32}$ Broad and Fleming, Nella Last's War, 115.
} 
mother expressed her gratitude to Nella for the strength and support she had given the mothers in their volunteer group. Nella later that day wrote:

May God pity women a poignant cry for us all. I look at Mrs. Hockey sometimes. I said to her one day,' My dear, you are an example to us all. I pray if I've ever to meet a trouble like you I can have your courage.' She said, 'You will never know how all your friendship and kindness in the room meant - and does mean to me. I feel I'm not alone. Just one, in a group of mothers, strained and anxious - but my strain is over. ${ }^{33}$

As the intensity of the war built, Nella's worry and fear for Cliff's safety grew, and her thoughts and feelings turned to the strength and courage the mothers in the volunteer group gave to each other during the war years. Thursday, 19 August 1943 the diarist expresses her sorrow for the women in her volunteer group:

My heart aches and, even in that small circle, the bravery and courage, the 'going on' when only sons have been killed, when letters don't come, when their boys are taught to fight like savages if they are commandoes when they are trained and trained and trained, for bodies to endure, and go and kill other women's lads, to wipe the light from other mothers faces. ${ }^{34}$

Nella's life-writing was helping her to pen down her deepest fears and face the awful possibilities of losing her sons as some of her co-workers had already experienced.

The war years slipped by, one upon another, Nella began to feel a sense of losing herself to the continual work, carnage, and effects of the war that reached into every facet of those on the battlefront and home-front. On Sunday, 31 October 1943 Nella confided in her diary:

Am I growing old quickly - or is it the strain of ceaseless effort which tires me at times to my soul-case? It's a long time sense I felt the keenness that always seemed a part of me. Is this what 'war weary' means? Will I ever feel gay and irresponsible again? Feel I could sing because the sun shines? Look forward to a holiday? I think I'm digging myself into a deep rut, and soon I'll not be able to see out of it - only along it. Yet I never

\footnotetext{
${ }^{33}$ Broad and Fleming, Nella Last's War, 234.

${ }^{34}$ Ibid., 249.
} 
consciously worry. I chatter gaily at the Centre. It's queer to feel numb and hollow, instead of vital. ${ }^{35}$

The diary entries of Nella Last from December 30, 1943 to May 4, 1945 were lost in the confusion of the war before being sent to the University of Sussex where all Mass- Observation materials were stored during and after the war. The war in Europe was quickly coming to a close and Nella's thoughts were returning to home and her problems with Will. In her diary entry of Thursday, 10 May 1945 the diarist once again confides in her diary that she will not return to the life she lived before the war:

I love my home dearly, but as a home rather than a house. The latter can make a prison and a penance, if a woman makes too much of a fetish of cleaning and polishing. But I will not, cannot, go back to the narrowness of my husband's 'I don't want anyone else's company but yours - why do you want anyone else?' I looked at his placid, blank face and marvelled at the way he had managed to dominate me for all our married life, at how, to avoid hurting him, I had tried to keep him in a good mood, when a smacked head would have been the best treatment. His petulant moods only receive indifference now. I know I speak sharply at times, I know I'm 'not the sweet woman I used to be' - but then I never was! Rather was I a frayed, battered thing, with nerves kept in control by effort that at times became too much, and 'nervous breakdowns' were the result. No one would ever give me one again, no one. ${ }^{36}$

It is apparent that Nella's diary entries she so faithfully recorded was not merely from a standpoint of "dutiful active citizenship" or simply from the perspective of "looking for meaning and purpose" in her life as Hinton had theorized of most Mass- Observation writers. ${ }^{37}$ More accurately, when reading Nella's diary, one can witness the diarist sharing victories she had claimed through volunteer work, as well as intimate, personal details with a confidant, a companion, and perhaps

\footnotetext{
${ }^{35}$ Broad and Fleming, Nella Last's War, 250.

${ }^{36}$ Ibid., 274.

${ }^{37}$ Hinton, Nine Wartime Lives, 2.
} 


\section{Patricia Brand}

in a way that "close woman friend" she had wished for the first day she wrote in her diary in $1939 .{ }^{38}$

Nella had been dedicated to her war-work and volunteerism for many reasons. Hospital Supply supervisors, the head of WVS, Red Cross organizers as well as co-workers recognized Nella's talent and abilities that she had been unaware of prior to the war. Their appreciation of her contribution bolstered Nella's selfimage and helped to build a feeling of independence she had never experienced before. Nella's creative energy, perseverance, and determination to do anything to help in the war cause inspired her colleagues at a time when they needed it most. Clearly, the work and selfless acts of Nella and the women volunteers she worked with in the war cause could not be attributed merely to a "testimony either to the long after-life of Victorian notions of 'character', or as skirmishes in a struggle for female equality in the intimate sphere," as suggested by Hinton. ${ }^{39}$ Rather, this was a network of women sharing their strengths and weaknesses, and their hopes and sorrows in bold actions for survival.

The diarist accomplished all she set out to do at the beginning of the war. She survived the terror and destruction of the war and managed through bold efforts to avoid another nervous breakdown. Cliff had been wounded, but recuperated, and both beloved sons came home safely. Arthur married and presented Nella and Will with two grandchildren. Nella acquired the political space in her marriage she desired through volunteerism and Mass-Observation writing; but remained by Will's side the rest of their life as she said was her duty to do. She also kept the promise she made to Cliff. In the Thursday, 9 January 1941 entry Nella wrote that Cliff said, "Don't change dearie - ever- fight hard against changing." 40 The devoted mother pondered her son's request and then promised him, "I'll never change, in that I love my boys, and as long as I've health and strength I'll keep the home fires burning." 41 Unlike most Mass-Observation writers who quit

\footnotetext{
${ }^{38}$ Broad and Fleming, Nella Last's War, 2.

${ }^{39}$ Hinton, Nine Wartime Lives, 204.

${ }^{40}$ Broad and Fleming, Nella Last's War, 92.

${ }^{41}$ Ibid., 93.
} 
writing their diary at the end of the war, Nella continued writing for MassObservation until 1966. She died in 1968, as did Will.

One of Nella's greatest ambitions was to write books, she said, "I've written enough letters to fill a few books - in words - and the boys tell me I've given them more pleasure than if I'd written best-sellers!" ${ }^{42}$ Dorothy Sheridan, MassObservation archivist at the University of Sussex, writes of the collection of papers that survived the war:

When the collection reached Sussex, it was in poor physical condition - the papers were trussed up in dusty old folders with string and perished elastic bands. They had been ravaged by mice and different sorts of fungi and eroded by rusty paper clips. Considering their history, which included the London Blitz and several moves on the backs of lorries, not to mention a flood or two; it is surprising that so much actually did survive. ${ }^{43}$

The woman known as Housewife 49, because she was forty-nine- years- old when the war began and when she started writing for Mass-Observation, continued to reach her goals even after her death. All of the diary entries and written materials the diarist had devotedly written in times of stress and great peril were compiled, and as Nella Last had predicted she had indeed written two books, Nella Last's War and Nella Last's Peace.

${ }^{42}$ Broad and Fleming, Nella Last's War, 11.

${ }^{43}$ Dorthy Sheridan, Wartime Women: An Anthology of Women's Wartime Writing for Mass Observation, 1937-1945 (London: William Heinermann Ltd., 1990), 266. 